\title{
Cypermethrin and Ivermectin Resistance in Field Populations of Rhipicephalus Sanguineus Sensu Lato (Latrielle, 1806) Collected From Dogs in South India
}

\section{Prathyusha Sunkara \\ NTR College of Veterinary Science \\ Sudhkar Krovvidi \\ NTR College of Veterinary Science \\ Jyothisree Ch \\ NTR College of Veterinary Science}

Sreedevi Chennuru ( $\square$ sdevichennuru@rediffmail.com )

NTR COLLEGE OF VETERINARY SCIENCE https://orcid.org/0000-0002-5754-4290

\section{Research Article}

Keywords: Ivermectin, Cypermethrin, Resistance, Target site insensitivity, Rhipicephalus sanguineus sensu lato, India

Posted Date: June 25th, 2021

DOl: https://doi.org/10.21203/rs.3.rs-637329/v1

License: (1) (1) This work is licensed under a Creative Commons Attribution 4.0 International License. Read Full License

Version of Record: A version of this preprint was published at Veterinary Research Communications on September 18th, 2021. See the published version at https://doi.org/10.1007/s11259-021-09830-2. 


\section{Abstract}

The abuse of acaricides for control of Rhipicephalus sanguineus sensu lato ticks led to a strong selection pressure for acaricide resistance. Data on acaricide resistance in $R$. sanguineus s.l. populations from India is meager though veterinarians frequently report treatment failures. The present study was aimed to characterize the level of resistance in $R$. sanguineus s.l. against most commonly used drugs, cypermethrin and ivermectin in Andhra Pradesh, south India. Fourteen adult female tick populations were collected from naturally infested dogs at veterinary clinics, residence and stray dog in nine state municipal corporations/municipalities. Information on the history of dog treatment with acaricides was obtained by interviewing dog owners. The larval packet test (LPT) and larval immersion test (LIT) were used on the larvae of ticks to test for resistance to cypermethrin and ivermectin, respectively. Mortality data of each tick population was analyzed by probit analysis. Corresponding to the most susceptible population, thirteen (92.6\%) and six (42.9\%) tick populations were regarded as resistant to cypermethrin and ivermectin, respectively. The phenotypic level of cypermethrin (resistance ratios at LC50\% varied from 1.55 to 13.29) and ivermectin (resistance ratios at LC50\% ranged from 1.16 to 4.79 ) resistance varied distinctly between the populations. Additionally, all the populations were tested using PCR to demonstrate the frequency of the point mutation in sodium channel gene that corresponds with resistance of $R$. sanguineus s.l. to cypermethrin. A nucleotide substitution (T2134C) on domain III segment VI of the sodium channel gene was noticed in phenotypically resistant tick populations on DNA sequencing. Ivermectin resistance in the brown dog ticks is reported for the first time from India.

\section{Introduction}

Rhipicephalus sanguineus sensu lato (Latrielle 1806), the brown dog tick, is a three-host tick that feeds principally on dogs and infrequently humans, and transmits various pathogens of veterinary and public health importance. These ticks complete more than $95 \%$ of their lifecycle off the host i.e., in the environment, and dog serves as the principal disseminating agent (Needham and Teel 1991). In consequence, transfer of ticks between locations is limited to dog visitations to veterinary clinics, or when infested dogs visit uninfested homes and kennels or vice versa. Rhipicephalus sanguineus are generally controlled using topical (oranophosphates, synthetic pyrethroids and amidines) and systemic (macrocyclic lctones) acaricides to infested hosts and some times in the surroundings. This confined genetic exchange together with prolonged use and abuse of acaricides contributed favourable circumstances for selection of acaricide resistant populations. Across the globe, acaricide resistance in the brown dog ticks, $R$. sanguineus has been reported (Rodriguez-Vivas et al. 2017a; Becker et al. 2015).

The resistance is more concerned in $R$. sanguineus populations that are under selective pressure from different classes of acaricides through exposure to on host and/or environment treatments. The use of DDT has been shown to confer cross-resistance to pyrethroids, in Aedes aegypti due to metabolic detoxification and target site insensitivity (Brengues et al. 2003). Cypermethrin and ivermectin are the commonly used acaricides in dogs against ticks in different parts of India as well as Andhra Pradesh (AP), south India. During epidemiological surveillance of ectoparasitic infections in dogs in AP, ticks were the highly prevalent ectoparasites and $R$. sanguineus was the exclusive species identified (Sowjanya 2019). Tick populations 
resistant to pyrethroids and ivermectin are doubted in India, depending on claims from pet owners and veterinarians that quote regular ineffective efforts to control infestations in homes, dog kennels and on dogs using these applications. Literature on acaricide resistance in $R$. sanguineus s.l. populations from India is restricted to deltamethrin resistance (Mathivathani et al. 2011; Shyma et al. 2019).

Detection of resistance to regularly used chemotherapeutic agents has become imperative to avoid both indiscriminate uses of drugs as well as futile expenditure incurred and to device alternate control strategies in case of resistance. Acaricide resistance can occur through reduced cuticular penetration, metabolic detoxification, and target site insensitivity. Resistant strains of ticks can be diagnosed by scrutinizing tick populations using bioassays to compare susceptibility between populations and molecular assays for genotyping of resistance (FAO 2004). Bioassays have been used for determining pyrethroids and ivemectin resistance in $R$. sanguineus populations (Rodriguez-Vivas et al. 2017a; Becker et al. 2019). A point mutation conferring target site insensitivity to pyrethroids is common and has been observed in ticks (Guerrero et al. 2001). Klafke et al. (2017) sequenced a highly conserved region of the sodium channel gene in $R$. sanguineus, and indicated that resistance to pyrethroids is correlated with point mutation (T2134C) on domain III segment VI of the sodium channel gene. The SNP of thymine ( $T$ ) to cytosine (C) at nucleotide 2,134 contributed an amino acid substitution from phenylalanine to leucine. Recently, Tucker et al. (2017) developed and evaluated a molecular assay to determine the pyrethroid resistance genotypes in multiple field-collected phenotypically permethrin-resistant $R$. sanguineus populations of Florida and Texas and confirmed genotypic correlation with phenotypic resistance expressing individual $R$. sanguineus. Owing to, in the present study an attempt has been made to characterize the level of resistance in Indian $R$. sanguineus s.l. populations against cypermethrin and ivermectin.

\section{Materials And Methods \\ 2.1 Study area}

The study was conducted in the state of Andhra Pradesh, India. Andhra Pradesh is a state in southern India and lies between $12^{\circ} 41^{\prime}$ and $19.07^{\circ} \mathrm{N}$ latitude and $77^{\circ}$ and $84^{\circ} 40^{\prime} \mathrm{E}$ longitude. Among the other states, which are situated on the country's coastal area, AP has got a coastline of around $974 \mathrm{~km}$, which gives it the 2nd longest coastline in the nation. The climate of AP is generally hot and humid. Mean annual temperature of the state is $33.2^{\circ} \mathrm{C}$. At certain places the temperature is as high as $45^{\circ} \mathrm{C}$ on a summer day. The summer season in this state generally extends from March to June. During these months the moisture level is quite high. The summer is followed by the monsoon season, which starts during June and continues till September. Annual normal rainfall of the state is $906 \mathrm{~mm}$. These environmental conditions provide favourable and conducive conditions for the survival and propagation of ticks and $R$. sanguineus is the major tick infesting canines.

\subsection{Ticks and chemicals}

Engorged female ticks were collected from naturally infested dogs attending veterinary polyclinics and veterinary hospitals in certain municipalities/municipal corporations of AP. Ticks were placed in clean vials covered with muslin cloth allowing air to circulate. After this, ticks were transported, within two days at most, 
to the Parasitology laboratory, NTR College of Veterinary Science, Gannavaram, AP for further morphological identification and to maintain them under controlled conditions until bioassays were carried out. Interviews were conducted with dog owners visiting veterinary clinics where ticks were collected to collect data on areas in which dogs lived and on acaricides used in the last four or five years to control tick infestations. Ticks were identified to the species $R$. sanguineus s.l. under a stereomicroscope (Carl Zeiss Microscopy GmbH, Stemi 508) analysing the morphological characteristics. Tick populations were named by the municipality/municipal corporation in which they were collected, with multiple collections from same locations were numbered sequentially (Table 1). Technical grade alpha-cypermethrin and ivermectin were procured from pharmaceutical companies (Sigma-Aldrich, USA) and were diluted to prepare stock solutions. Alpha-cypermethrin was diluted in methanol to prepare the stock solution of $10,000 \mathrm{ppm}$, which was then diluted in distilled water to prepare different concentrations of the drug. Ivermectin was diluted in absolute ethanol to prepare a $1 \%$ stock solution. An ethanol solution containing $2 \%$ Triton X-100 (Sigma-Aldrich, USA) was diluted with distilled water to facilitate $1 \%$ of the detergent (Eth-TX $1 \%$ ). Ethanol stock solution of IVM was then diluted in Eth-TX $1 \%$ for preparation of different concentrations of the drug. 
Table 1

Particulars of Rhipicephalus sanguineus sensu lato populations collected from dogs from Andhra Pradesh, south India

\begin{tabular}{|c|c|c|c|c|c|}
\hline $\begin{array}{l}\text { District } \\
\text { (Geographic } \\
\text { coordinates) }\end{array}$ & $\begin{array}{l}\text { Municipality/ } \\
\text { Municipal } \\
\text { corporation }\end{array}$ & $\begin{array}{l}\text { Sample } \\
\text { ID }\end{array}$ & Source & $\begin{array}{l}\text { History of } \\
\text { acaricides use }\end{array}$ & $\begin{array}{l}\text { Frequency of } \\
\text { application }\end{array}$ \\
\hline \multirow[t]{5}{*}{$\begin{array}{l}\text { Krishna } \\
16.6100^{\circ} \mathrm{N}, \\
80.7214^{\circ} \mathrm{E}\end{array}$} & Vijayawada & BZA1 & $\begin{array}{l}\text { Veterinary } \\
\text { Clinic }\end{array}$ & $\begin{array}{l}\text { Ivermectin, } \\
\text { Cypermethrin, } \\
\text { Amitraz }\end{array}$ & Frequent \\
\hline & & BZA2 & $\begin{array}{l}\text { Veterinary } \\
\text { Clinic }\end{array}$ & $\begin{array}{l}\text { Ivermectin, } \\
\text { Cypermethrin, } \\
\text { Fipronil }\end{array}$ & Frequent \\
\hline & & BZA3 & $\begin{array}{l}\text { Veterinary } \\
\text { Clinic }\end{array}$ & $\begin{array}{l}\text { Ivermectin, } \\
\text { Cypermethrin, } \\
\text { Amitraz }\end{array}$ & Occasional \\
\hline & Machilipatnam & MTM1 & $\begin{array}{l}\text { Veterinary } \\
\text { Clinic }\end{array}$ & $\begin{array}{l}\text { Ivermectin, } \\
\text { Cypermethrin, } \\
\text { Fipronil }\end{array}$ & Frequent \\
\hline & & MTM 2 & Residence & $\begin{array}{l}\text { Ivermectin, } \\
\text { Cypermethrin, } \\
\text { Amitraz }\end{array}$ & Frequent \\
\hline West Godavari & Tanuku & TNK & $\begin{array}{l}\text { Veterinary } \\
\text { Clinic }\end{array}$ & Ivermectin, & Frequent \\
\hline \multirow[t]{2}{*}{$\begin{array}{l}16.9174^{\circ} \mathrm{N} \\
81.3399^{\circ} \mathrm{E}\end{array}$} & & & & $\begin{array}{l}\text { Fipronil, } \\
\text { Cypermethrin }\end{array}$ & \\
\hline & Eluru & ELR & $\begin{array}{l}\text { Veterinary } \\
\text { Clinic }\end{array}$ & $\begin{array}{l}\text { Ivermectin, } \\
\text { Cypermethrin }\end{array}$ & Occasional \\
\hline $\begin{array}{l}\text { Vishakapatnam } \\
17.6868^{\circ} \mathrm{N} \\
83.2185^{\circ} \mathrm{E}\end{array}$ & Vishakapatnam & VSP1 & $\begin{array}{l}\text { Veterinary } \\
\text { Clinic }\end{array}$ & $\begin{array}{l}\text { Ivermectin, } \\
\text { Fipronil, } \\
\text { Cypermethrin }\end{array}$ & Frequent \\
\hline
\end{tabular}




\begin{tabular}{|c|c|c|c|c|c|}
\hline $\begin{array}{l}\text { District } \\
\text { (Geographic } \\
\text { coordinates) }\end{array}$ & $\begin{array}{l}\text { Municipality/ } \\
\text { Municipal } \\
\text { corporation }\end{array}$ & $\begin{array}{l}\text { Sample } \\
\text { ID }\end{array}$ & Source & $\begin{array}{l}\text { History of } \\
\text { acaricides use }\end{array}$ & $\begin{array}{l}\text { Frequency of } \\
\text { application }\end{array}$ \\
\hline & & VSP 2 & $\begin{array}{l}\text { Veterinary } \\
\text { Clinic }\end{array}$ & $\begin{array}{l}\text { Ivermectin, } \\
\text { Cypermethrin, } \\
\text { Fipronil }\end{array}$ & Frequent \\
\hline $\begin{array}{l}\text { Guntur } \\
16.3067^{\circ} \mathrm{N} \text {, } \\
80.4365^{\circ} \mathrm{E}\end{array}$ & Guntur & GNT & $\begin{array}{l}\text { Veterinary } \\
\text { Clinic }\end{array}$ & $\begin{array}{l}\text { Ivermectin, } \\
\text { Cypermethrin, } \\
\text { Fipronil }\end{array}$ & Frequent \\
\hline $\begin{array}{l}\text { YSR Kadapa } \\
14.4673^{\circ} \mathrm{N} \\
78.8242^{\circ} \mathrm{E}\end{array}$ & Kadapa & $\mathrm{KDP}$ & $\begin{array}{l}\text { Veterinary } \\
\text { Clinic }\end{array}$ & $\begin{array}{l}\text { Ivermectin, } \\
\text { Cypermethrin, } \\
\text { Fipronil }\end{array}$ & Occasional \\
\hline \multirow[t]{2}{*}{$\begin{array}{l}\text { Anantapur } \\
14.6819^{\circ} \mathrm{N}, \\
77.6006^{\circ} \mathrm{E}\end{array}$} & Anantapur & ATP1 & $\begin{array}{l}\text { Veterinary } \\
\text { Clinic }\end{array}$ & $\begin{array}{l}\text { Ivermectin, } \\
\text { Cypermethrin, } \\
\text { Fipronil }\end{array}$ & Frequent \\
\hline & & ATP 2 & $\begin{array}{l}\text { Veterinary } \\
\text { Clinic }\end{array}$ & $\begin{array}{l}\text { Ivermectin, } \\
\text { Cypermethrin, } \\
\text { Fipronil }\end{array}$ & Frequent \\
\hline $\begin{array}{l}\text { Kurnool } \\
15.8281^{\circ} \mathrm{N}, \\
78.0373^{\circ} \mathrm{E}\end{array}$ & Kurnool & $\mathrm{KNL}$ & Stray dog & Unknown & Unknown \\
\hline
\end{tabular}

\subsection{Bioassay}

In the laboratory, ticks were placed in glass vials after washing in distilled water, and immediately incubated under laboratory conditions at $28 \pm 1^{\circ} \mathrm{C}, \mathrm{RH} 85 \pm 5 \%$ (Cen-Aguilar et al. 1998) and a photoperiod of LD 12: 12 $\mathrm{h}$ to allow the laying of eggs. Egg masses from the same collection location were mixed and separated into aliquots in glass vials and returned to the incubator for same laboratory conditions. Live larvae aged 14-21 days were used in bioassays. For screening of resistance to multiple acaricides in tick species, the Food and Agriculture Organization (UN) larval packet test (FAO LPT) has been used and is considered a valuable bioassay in the rapid diagnosis of acaricide resistance. The LPT can also be used for macrocyclic lactones (MLs) but preliminary results at Commonwealth Scientific and Industrial Research Organisation (CSIRO), Australia, have shown that the larval immersion test (LIT) is much more sensitive (FAO 2004).

\subsubsection{Larval immersion test (LIT)}


The LIT was performed according to the method described by Rodriguez-Vivas et al. (2017b) on the larvae of $R$. sanguineus s.I. ticks to find ivermectin resistance. Eight doses of IVM in Eth-TX 1\% were obtained through three-fold dilutions from the highest $0.36 \%$ concentration. Concentrations used for predictive dose responses were (in ppm): 3600, 1200, 400, 133, 44, 15, 5, and 2. Eth-TX 1\% were used as the control solution. Concisely, $0.75 \mathrm{~mL}$ of each test concentration was transferred into $1.5 \mathrm{~mL}$ microcentrifuge tubes and approximately 200-300 larvae were added using a paintbrush. The larvae were immersed for $10 \mathrm{~min}$ and periodically agitated. The tubes were then opened and groups of about 100 larvae were transferred with another paintbrush to a filter paper $(3.75 \times 8.5 \mathrm{~cm})$ that was folded and closed with adhesive tapes forming a packet. The test was performed for each concentration of ivermectin and a control (larvae immersed in Eth-TX 1\%) in triplicate. Finally, the packets were incubated at $28 \pm 1^{\circ} \mathrm{C}$ and $85 \pm 5 \% \mathrm{RH}$ for $24 \mathrm{~h}$. After $24 \mathrm{~h}$, the mortality of larvae in each drug concentration and control was assessed.

\subsubsection{Larval packet test (LPT)}

A larval packet test as described (FAO 1971) was used to determine the resistance to cypermethrin. Briefly, $0.5 \mathrm{~mL}$ of each concentrations of alpha-cypermethrin in distilled water (prepared from stock solution) was used to impregnate 3.75 x 8.5cm filter paper rectangles (541 Whatman, Maidstone, Kent, UK). Concentrations used were (in ppm): 3000, 1000, 300, 100, 30, 10, 3 and 1. Subsequently, filter papers were allowed to dry for $30 \mathrm{~min}$ in incubator at $37^{\circ} \mathrm{C}$. Then, papers were folded and closed with adhesive tape to form packets. Then approximately 100 larvae were inserted into the packet, and the top of each packet was closed with adhesive tape. Subsequently, the packets were maintained at $28 \pm 1^{\circ} \mathrm{C}$ and $85 \pm 5 \% \mathrm{RH}$ in an incubator for $24 \mathrm{~h}$. Three replicates of every concentration of alpha-cypermethrin and a control (larvae submerged in distilled water) were used. Following incubation, the number of live and dead larvae in each packet including control was counted.

\subsection{Molecular assay}

Larvae used were those that survived the highest exposure dose of the LPT and could not survive even in lowest exposure dose of LPT, which previously were stored at $-80^{\circ} \mathrm{C}$. DNA was extracted from individual larva by salting out method using the protocol of Rodriguez et al. (2014). Fourteen distinct populations were tested by polymerase chain reaction using the primers of Tucker et al. (2017) to demonstrate the frequency of the point mutation in sodium channel gene that corresponds with resistance of $R$. sanguineus s.l. to cypermethrin. DNA of larvae that survived in highest cypermethrin concentration and larvae that died even in the lowest concentration in LPT were initially selected, subjected for PCR and subsequent sequencing to identify the SNP at sodium channel gene, due to the unavailability of reference susceptible and resistant tick populations. Primers FG-228 and BDT-227 were used to produce a 104 base pair PCR product, which was used for sequencing. The PCR was optimized at initial denaturation of $96^{\circ} \mathrm{C}$ for 3 min, followed by 40 cycles of $94^{\circ} \mathrm{C}$ for $60 \mathrm{~s}, 48^{\circ} \mathrm{C}$ for $60 \mathrm{~s}$ and $72^{\circ} \mathrm{C}$ for $60 \mathrm{~s}$ with a final extension of $72^{\circ} \mathrm{C}$ for $7 \mathrm{~min}$. Reaction was carried in a final volume of $15 \mu \mathrm{L}$ containing 2 ng genomic DNA, $7.5 \mu \mathrm{L}$ of master mix (Green dye PCR master mix (2x), Takara) and 5 pmol of each forward and reverse primers.

Based on the sequencing results both susceptible and resistant larval DNA were selected and used to optimize PCR assay with respective primer sets (BDT-227 and either SUS-F or RES-F) to identify specific annealing temperature that differentiate susceptible and resistant genotypes (presence or absence of $\mathrm{C} / \mathrm{T}$ ). 
An annealing temperature gradient of $48^{\circ} \mathrm{C}$ to $52^{\circ} \mathrm{C}$ was used to optimize specificity. On each sample two reactions were used separately due to the identical amplicon size produced by both primer sets. The primers BDT-227 and either SUS-F to amplify phenotypic susceptible tick DNA or RES-F to amplify phenotypic resistant tick DNA were employed to generate a 69 base pair amplicon at the site of the point mutation (Supplementary data I). Then, the optimised PCR was performed on each sample in a population to determine heterozygous, or homozygous resistant or susceptible genotypes without the need for sequence analysis. PCR reaction for genotyping used the same master mix as explained above. Except the annealing temperature $48.2^{\circ} \mathrm{C}$, the PCR conditions were alike as detailed prior. A negative control (water in substitution of DNA) was run along with the samples at every PCR setup. PCR amplicons of $104 \mathrm{bp}$ and $69 \mathrm{bp}$ were visualized on $2.0 \%$ and $3.5 \%(\mathrm{w} / \mathrm{v})$ agarose gel containing ethidium bromide respectively, and photographed under UV light (Gel doc, Eppendorf).

PCR amplicons were purified and were subjected to Sanger's sequencing. Sequencing results were analyzed using Codon Code Aligner to validate the presence of the susceptible sequence or the resistant sequence with the SNP (at nucleotide 2,134 on domain III segment $\mathrm{VI}$ ) in the sodium channel of the $R$. sanguineus s.I.

\subsection{Statistical Analysis}

Data from assays was transformed by probit analysis against the logarithm of concentration (Supplementary data II). Dose dependent data were calculated for estimating $\mathrm{LC}_{50}$ and is used for Resistance ratios (RRs) purpose as $\mathrm{LC}_{50}$ can be most accurately detected. Due to lack of reference susceptible $R$. sanguineus s.I. strain, the sampled population hither mentioned as "KNL" with the lowest LC50\% was used to evaluate the RRs. Resistance ratios were calculated by dividing the $\mathrm{LC}_{50}$ value for the field population by the $\mathrm{LC}_{50}$ value for the reference susceptible strain. Differences between $\mathrm{LC} 50 \%$ estimates of the sampled tick population and the "KNL" population were designated as statistically significant if their $95 \%$ Cls did not overlap (Robertson and Preisler 1992). Resistance or susceptibility status to cypermethrin and ivermectin for every $R$. sanguineus s.l. population examined was decided if RR at $50 \%$ was statistical different from the KNL population. The sampled populations were classified as susceptible when the RR was lower than 1.5, with incipient resistance when the RR was between 1.5 and 2 and resistant when the RR was higher than 2 (Becker et al. 2019).

Genotype and allele frequencies were calculated as per Falconer and Mackay (2009). The chi-square test of goodness of fit was carried out with the observed and the expected numbers to check whether the worm population was in Hardy - Weinberg equilibrium. F- Statistics were estimated for analysis of the population structure of the ticks with respect to their resistance to cypermethrin.

\section{Results}

\subsection{Bioassays}

The data on $\mathrm{LC}_{50}$ and $\mathrm{LC}_{99}$ values of cypermethrin and the level of resistance for fourteen $R$. sanguineus s.l. populations sampled from the study area are presented in Table 2. 
Table 2

Results of LPT with cypermethrin against $R$. sanguineus s.l. populations collected from Andhra Pradesh, India

\begin{tabular}{|c|c|c|c|c|c|c|}
\hline Tick populations & $x^{2}$ & Slope \pm SE & $\mathrm{LC}_{50}\left(\mathrm{Cl}_{95 \%}\right)(\mathrm{ppm})$ & $\mathrm{LC}_{99 \%}\left(\mathrm{Cl}_{95 \%}\right)(\mathrm{ppm})$ & $\mathbf{R R}_{50 \%}$ & $\mathrm{RR}_{99 \%}$ \\
\hline \multirow[t]{2}{*}{ ATP 2} & 71.2 & $1.7 \pm 0.04$ & 275.6 & 5758.7 & $13.3^{\mathrm{b}}$ & $2.8^{\mathrm{a}}$ \\
\hline & & & $(231.7-327.9)$ & (3861.1-8588.9) & & \\
\hline \multirow[t]{2}{*}{ MTM 2} & 68.3 & $1.7 \pm 0.05$ & 240.2 & 6043.4 & $11.6^{\mathrm{b}}$ & $2.9^{a}$ \\
\hline & & & $(198.8-290.1)$ & (3824.6-9549.6) & & \\
\hline \multirow[t]{2}{*}{ MTM 1} & 76.9 & $1.6 \pm 0.03$ & 187.6 & 9701.7 & $9.1^{\mathrm{b}}$ & $4.6^{b}$ \\
\hline & & & $(148.9-236.4)$ & $(5108.2-18425.7)$ & & \\
\hline \multirow[t]{2}{*}{ VSP 1} & 24.8 & $1.4 \pm 0.03$ & 61.7 & 5477.7 & $3^{b}$ & $2.6^{\mathrm{a}}$ \\
\hline & & & $(48.6-78.2)$ & $(2806.2-10692.5)$ & & \\
\hline \multirow[t]{2}{*}{ ATP 1} & 36.1 & $1.3 \pm 0.03$ & 52.0 & 7595.9 & $2.5^{\mathrm{b}}$ & $3.6^{\mathrm{a}}$ \\
\hline & & & $(40.2-67.4)$ & $(3504.0-16466.0)$ & & \\
\hline \multirow[t]{2}{*}{ GNT } & 46.9 & $1.2 \pm 0.03$ & 38.7 & 21374.9 & $1.9^{b}$ & $10.2^{b}$ \\
\hline & & & $(28.7-52.2)$ & (7914.0-57731.3) & & \\
\hline \multirow[t]{2}{*}{ TNK } & 12.7 & $1.4 \pm 0.03$ & 37.1 & 2890 & $1.8^{\mathrm{b}}$ & $1.4^{\mathrm{a}}$ \\
\hline & & & $(29.5-46.7)$ & $(1539.7-5424.7)$ & & \\
\hline \multirow[t]{2}{*}{ VSP 2} & 13.2 & $1.4 \pm 0.04$ & 36.2 & 2966.2 & $1.8^{\mathrm{b}}$ & $1.4^{\mathrm{a}}$ \\
\hline & & & $(28.7-45.7)$ & $(1563.7-5626.6)$ & & \\
\hline \multirow[t]{2}{*}{ KDP } & 8.4 & $1.4 \pm 0.05$ & 35.8 & 1950.4 & $1.7^{\mathrm{b}}$ & $0.9^{a}$ \\
\hline & & & $(28.8-44.5)$ & $(1097.7-3465.7)$ & & \\
\hline \multirow[t]{2}{*}{ BZA 3} & 20.3 & $1.3 \pm 0.03$ & 35.7 & 4827.6 & $1.7^{\mathrm{b}}$ & $2.3^{a}$ \\
\hline & & & $(28.0-45.5)$ & (2398.8-9715.8) & & \\
\hline \multirow[t]{2}{*}{ BZA 2} & 47.5 & $1.1 \pm 0.03$ & 35.6 & 25807.2 & $1.7^{\mathrm{b}}$ & $12.3^{b}$ \\
\hline & & & $(26.1-48.5)$ & (8989.5-74088.3) & & \\
\hline \multirow[t]{2}{*}{ ELR } & 10.9 & $1.3 \pm 0.04$ & 32.2 & 2996.7 & $1.6^{\mathrm{a}}$ & $1.4^{\mathrm{a}}$ \\
\hline & & & $(25.5-40.8)$ & $(1566.5-5732.7)$ & & \\
\hline
\end{tabular}

Х2: Chi square; SE: Standard error; LC: Lethal concentration; Cl: Confidence interval; RR: Resistance ratio Different letter in the column show statistical difference Populations were considered statistically different $(\mathrm{P}<0.05)$ when the $\mathrm{Cl}_{95 \%}$ of the $\mathrm{LC}_{50}$ did not overlap. 


\begin{tabular}{|c|c|c|c|c|c|c|}
\hline Tick populations & $x^{2}$ & Slope \pm SE & $\mathrm{LC}_{50}\left(\mathrm{Cl}_{95 \%}\right)(\mathrm{ppm})$ & $\mathrm{LC}_{99 \%}\left(\mathrm{Cl}_{95 \%}\right)(\mathrm{ppm})$ & $\mathbf{R R}_{50 \%}$ & $\mathbf{R R}_{99 \%}$ \\
\hline \multirow[t]{2}{*}{ BZA 1} & 16.4 & $1.3 \pm 0.03$ & 32.1 & 4850.2 & $1.6^{\mathrm{a}}$ & $2.3^{\mathrm{a}}$ \\
\hline & & & $(24.9-41.5)$ & $(2301.3-10222.1)$ & & \\
\hline \multirow[t]{2}{*}{ KNL } & 5.1 & $1.3 \pm 0.04$ & 20.7 & 2092.7 & - & - \\
\hline & & & $(16.3-26.3)$ & $(1081.5-4049.2)$ & & \\
\hline \multicolumn{7}{|c|}{ Х2: Chi square; SE: Standard error; LC: Lethal concentration; Cl: Confidence interval; RR: Resistance ratio } \\
\hline \multicolumn{7}{|c|}{ Different letter in the column show statistical difference } \\
\hline \multicolumn{7}{|c|}{ Populations were considered statistically different $(\mathrm{P}<0.05)$ when the $\mathrm{Cl}_{95 \%}$ of the $\mathrm{LC}_{50}$ did not overlap. } \\
\hline
\end{tabular}

The $\mathrm{LC}_{50}$ and $\mathrm{LC}_{99}$ of the most susceptible population (KNL) was 20.732 and 2092.67 ppm respectively, which was collected from a stray dog. The RRs $\left(a t C_{50}\right)$ of the tested populations ranged from 1.55 to 13.29 showing inter-population variation in the phenotypic level of cypermethrin resistance. No tested population was found to be susceptible when compared with KNL population. Eight populations, with RR ranging from 1.55 to 1.87 were categorized as incipient resistance and five populations were categorized as resistant (RR ranging from 2.51 to 13.29). Only ATP2 (RR: 13.29), MTM2 (RR: 11.58) and MTM1 (RR: 9.05) populations showed high level of resistance. The populations categorized as resistant were with confirmed exposure to cypermethrin since three or four years. Though, low inter-population variation in the phenotypic level of cypermethrin resistance was apparent in between ATP2, MTM1, and MTM2 populations ( $\mathrm{LC}_{50}: 9.05$ to 13.29), they exhibited distinct variation in the phenotypic level cypermethrin resistance with the rest of the populations.

In LIT, $\mathrm{LC}_{50}$ and $\mathrm{LC}_{99}$ values (10.123 and $447.77 \mathrm{ppm}$, respectively) of ivermectin for KNL population were significantly lower than other populations (Table 3). The RRs (at $\mathrm{LC}_{50}$ ) of the tested populations ranged from 1.16 to 4.79. In comparison with KNL population, seven (RR value of less than 1.5), three (RR value ranging from 1.5 to 1.73 ) and three (RR value ranging from 3.91 to 4.79 ) populations were categorized as susceptible, incipient resistance and resistant, respectively. All the populations classified as resistant and also susceptible were reported to be treated with ivermectin. The greatest ivermectin resistant BZA2 population was collected from veterinary clinic, Vijayawada and has been treated with ivermectin, cypermethrin, and fipronil. Out of three populations collected from Vijayawada, BZA1 and BZA2 were categorized as resistant populations and BZA3 was considered as incipient resistant population. The highest ivermectin $\mathrm{RR}_{50}$ of 4.3 was noticed in the ATP1 population that had a cypermethrin $\mathrm{RR}_{50}$ of 2.51 , showing resistance to both drugs. BZA2, ATP1 and BZA1 populations exhibited obvious variation in the phenotypic level of ivermectin resistance with the rest of the populations, although, low inter-population variation in the phenotypic level of ivermectin resistance was apparent in between these three populations ( $\mathrm{LC}_{50}: 4.79$ to 3.91$)$. 
Table 3

Results of LIT with ivermectin against $R$. sanguineus s.I. populations collected from Andhra Pradesh, India

\begin{tabular}{|c|c|c|c|c|c|c|}
\hline Tick population & $x^{2}$ & Slope \pm SE & $\mathrm{LC}_{50}\left(\mathrm{Cl}_{95 \%)}(\mathrm{ppm})\right.$ & $\mathrm{LC}_{99 \%}\left(\mathrm{Cl}_{95 \%}\right)(\mathrm{ppm})$ & $\mathbf{R R}_{50 \%}$ & $\mathbf{R R}_{\mathbf{9 9} \%}$ \\
\hline \multirow[t]{2}{*}{ BZA 2} & 30.8 & $1.3 \pm 0.03$ & 48.5 & 11689.5 & $4.8^{b}$ & $26.1^{\mathrm{b}}$ \\
\hline & & & $(37.1-63.4)$ & (5053.3-27040.4) & & \\
\hline \multirow[t]{2}{*}{ ATP1 } & 22.6 & $1.4 \pm 0.04$ & 43.5 & 5233.8 & $4.3^{b}$ & $11.7^{\mathrm{b}}$ \\
\hline & & & $(34.1-55.6)$ & $(2546.8-10755.8)$ & & \\
\hline \multirow[t]{2}{*}{ BZA 1} & 19.7 & $1.3 \pm 0.04$ & 39.6 & 6845.0 & $3.9^{b}$ & $15.3^{b}$ \\
\hline & & & $(30.7-51.1)$ & (3131.9-14960.5) & & \\
\hline \multirow[t]{2}{*}{ GNT } & 18.4 & $1.1 \pm 0.03$ & 17.5 & 7901.9 & $1.7^{\mathrm{a}}$ & $17.7^{\mathrm{b}}$ \\
\hline & & & $(12.9-23.7)$ & $(3115.5-20042.3)$ & & \\
\hline \multirow[t]{2}{*}{ BZA 3} & 9.8 & $1.2 \pm 0.03$ & 16.2 & 2675.7 & $1.6^{\mathrm{a}}$ & $6^{b}$ \\
\hline & & & $(12.6-20.9)$ & $(1326.4-5397.7)$ & & \\
\hline \multirow[t]{2}{*}{ VSP 2} & 7.3 & $1.2 \pm 0.04$ & 15.2 & 2355.9 & $1.5^{\mathrm{a}}$ & $5.3^{\mathrm{b}}$ \\
\hline & & & $(11.7-19.6)$ & $(1153.4-4812.4)$ & & \\
\hline \multirow[t]{2}{*}{ TNK } & 3.5 & $1.2 \pm 0.04$ & 14.8 & 1882.9 & $1.5^{\mathrm{a}}$ & $4.2^{\mathrm{b}}$ \\
\hline & & & $(11.6-19)$ & $(976.0-3632.7)$ & & \\
\hline \multirow[t]{2}{*}{ VSP 1} & 9.8 & $1.2 \pm 0.04$ & 13.5 & 2544.4 & $1.3^{\mathrm{a}}$ & $5.7^{b}$ \\
\hline & & & $(10.3-17.6)$ & $(1225.5-5282.6)$ & & \\
\hline \multirow[t]{2}{*}{ ELR } & 3.3 & $1.2 \pm 0.04$ & 12.9 & 1884.9 & $1.3^{\mathrm{a}}$ & $4.2^{b}$ \\
\hline & & & $(10-16.7)$ & $(941.9-3771.8)$ & & \\
\hline \multirow[t]{2}{*}{ ATP 2} & 4.6 & $1.2 \pm 0.04$ & 12.6 & 1610.6 & $1.3^{\mathrm{a}}$ & $3.6^{b}$ \\
\hline & & & $(9.8-16.2)$ & $(828.4-3131.5)$ & & \\
\hline \multirow[t]{2}{*}{ MTM 1} & 9.7 & $1.2 \pm 0.04$ & 12.0 & 1311.3 & $1.2^{\mathrm{a}}$ & $2.9^{a}$ \\
\hline & & & $(9.4-15.3)$ & $(704.1-2442.3)$ & & \\
\hline \multirow[t]{2}{*}{ MTM 2} & 14.1 & $1.2 \pm 0.04$ & 11.9 & 1758.5 & $1.2^{\mathrm{a}}$ & $3.9^{b}$ \\
\hline & & & $(9.1-15.4)$ & (885.3-3492.8) & & \\
\hline
\end{tabular}

Х2: Chi square; SE: standard error; LC: Lethal concentration, Cl: Confidence interval, RR: Resistance ratio Different letter in the column show statistical difference

Populations were considered statistically different $(\mathrm{P}<0.05)$ when the $\mathrm{Cl}_{95 \%}$ of the $\mathrm{LC}_{50}$ did not overlap. 


\begin{tabular}{|lllllll|}
\hline Tick population & $\chi 2$ & Slope $\pm S E$ & $\mathrm{LC}_{50}\left(\mathrm{Cl}_{95 \%}(\mathrm{ppm})\right.$ & $\mathrm{LC}_{99 \%}\left(\mathrm{Cl}_{95 \%}\right)(\mathrm{ppm})$ & $\mathrm{RR}_{\mathbf{5 0 \%}}$ & $\mathrm{RR}_{\mathbf{9 9}}$ \\
\hline $\mathrm{KDP}$ & 9.4 & $1.3 \pm 0.05$ & 11.7 & 1156.7 & $1.2^{\mathrm{a}}$ & $2.6^{\mathrm{a}}$ \\
\hline
\end{tabular}

\begin{tabular}{|llllll|} 
& & $(5.1-15.0)$ & $(556.6-2403.9)$ & \\
\hline KNL & 4.5 & $1.3 \pm 0.05$ & 10.1 & 447.8 & - \\
& & & $(8.2-12.5)$ & $(266.4-752.5)$ &
\end{tabular}

Х2: Chi square; SE: standard error; LC: Lethal concentration, Cl: Confidence interval, RR: Resistance ratio

Different letter in the column show statistical difference

Populations were considered statistically different $(\mathrm{P}<0.05)$ when the $\mathrm{Cl}_{95 \%}$ of the $\mathrm{LC}_{50}$ did not overlap.

\subsection{Molecular assays}

The PCR conditions were optimized by setting different time-temperature combinations for annealing process. On amplification, an expected fragment of 104 bp product (Fig. 1) was observed that was used for sequencing.

Oligonucleotide primers did not yield PCR product with negative control. Based on the sequencing results both susceptible (KNL) and resistant (ATP2) larval DNA were selected and used to optimize PCR assay to identify the SNP on domain III segment VI of the sodium channel. On screening of each sample with optimized PCR, the larvae were typed to heterozygous ('rS'), or homozygous resistant ('rr') or susceptible genotypes ('SS') (Fig. 2). The cypermethrin resistance-conferring sodium channel SNP was present in all the populations collected from AP, except in KNL population. The mutation was most frequent in the MTM2 population where $72 \%$ of the screened individuals presented a homozygous resistant ('rr') genotype and less frequent in VSP2 population where only $8 \%$ of the screened individuals presented a homozygous resistant ('rr') genotype.

The overall genotypic frequencies varied significantly $(P<0.01)$ with respect to sodium channel gene in the study area (Table 4). The overall frequency of 'rr' genotypes was high compared to that of ' $r S$ ' and 'SS' genotypes. On observing the genotypic frequencies within different populations of AP it revealed that there was no significant difference $(P>0.05)$ between the genotypes except in BZA2 $(P<0.01)$ population. The frequency of ' $r$ ' genotypes were more $(71.43 \%)$ in MTM2 tick population whereas the frequency of 'SS' was more $(50.0 \%)$ in BZA3 population. 
Table 4

Genotype frequencies at sodium channel gene mutation in populations of $R$. sanguineus s.l.

\begin{tabular}{|c|c|c|c|c|c|c|c|c|}
\hline \multirow{2}{*}{$\begin{array}{l}\text { Tick } \\
\text { population }\end{array}$} & \multirow{2}{*}{$\begin{array}{l}\% \\
\text { Survival } \\
\#\end{array}$} & \multirow{2}{*}{$\begin{array}{l}\text { No. of } \\
\text { individuals } \\
\text { tested }\end{array}$} & \multicolumn{3}{|c|}{ Genotypic frequency } & \multirow{2}{*}{$\chi_{\text {value }}^{2}$} & \multicolumn{2}{|c|}{ Allele frequency } \\
\hline & & & sS & rS & $\mathrm{Rr}$ & & $\begin{array}{l}\text { Susceptible } \\
\text { (S) }\end{array}$ & $\begin{array}{l}\text { Resistant } \\
\text { (r) }\end{array}$ \\
\hline $\mathrm{KNL}$ & 50 & 15 & $100.0(15)$ & - & - & - & 1 & - \\
\hline $\mathrm{ATP}_{2}$ & 97 & 22 & - & $\begin{array}{l}45.5 \\
(10)\end{array}$ & $\begin{array}{l}54.5 \\
(12)\end{array}$ & 1.9 & 0.23 & 0.77 \\
\hline $\mathrm{MTM}_{2}$ & 96 & 28 & $7.1(2)$ & $\begin{array}{l}21.4 \\
(6)\end{array}$ & $\begin{array}{l}71.4 \\
(20)\end{array}$ & 2.1 & 0.18 & 0.82 \\
\hline $\mathrm{MTM}_{1}$ & 90 & 20 & - & $\begin{array}{l}50.0 \\
(10)\end{array}$ & $\begin{array}{l}50.0 \\
(10)\end{array}$ & 2.1 & 0.25 & 0.75 \\
\hline VSP1 & 71 & 15 & $26.7(4)$ & $\begin{array}{l}40.0 \\
(6)\end{array}$ & $\begin{array}{l}33.3 \\
(5)\end{array}$ & 0.6 & 0.47 & 0.53 \\
\hline ATP1 & 66 & 10 & $30.0(3)$ & $\begin{array}{l}40.0 \\
(4)\end{array}$ & $\begin{array}{l}30.0 \\
(3)\end{array}$ & 0.4 & 0.50 & 0.50 \\
\hline GNT & 59 & 10 & $20.0(2)$ & $\begin{array}{l}50.0 \\
(5)\end{array}$ & $\begin{array}{l}30.0 \\
(3)\end{array}$ & 0.001 & 0.45 & 0.55 \\
\hline TNK & 62 & 12 & $33.3(4)$ & $\begin{array}{l}41.7 \\
(5)\end{array}$ & $\begin{array}{l}25.0 \\
(3)\end{array}$ & 0.3 & 0.54 & 0.46 \\
\hline $\mathrm{VSP}_{2}$ & 61 & 12 & $33.3(4)$ & $\begin{array}{l}58.3 \\
(7)\end{array}$ & $\begin{array}{l}8.3 \\
(1)\end{array}$ & 0.7 & 0.63 & 0.37 \\
\hline KDP & 62 & 12 & $33.3(4)$ & $\begin{array}{l}50.0 \\
(6)\end{array}$ & $\begin{array}{l}16.7 \\
(2)\end{array}$ & 0.02 & 0.58 & 0.42 \\
\hline $\mathrm{BZA}_{3}$ & 60 & 12 & $50.0(6)$ & $\begin{array}{l}25.0 \\
(3)\end{array}$ & $\begin{array}{l}25.0 \\
(3)\end{array}$ & 2.6 & 0.63 & 0.37 \\
\hline $\mathrm{BZA}_{2}$ & 57 & 15 & $13.3(2)$ & $\begin{array}{l}13.3 \\
(2)\end{array}$ & $\begin{array}{l}73.3 \\
(11)\end{array}$ & $5.1^{*}$ & 0.20 & 0.80 \\
\hline ELU & 59 & 10 & $30.0(3)$ & $\begin{array}{l}50.0 \\
(5)\end{array}$ & $\begin{array}{l}20.0 \\
(2)\end{array}$ & 0.001 & 0.55 & 0.45 \\
\hline $\mathrm{BZA}_{1}$ & 58 & 13 & $46.2(6)$ & $\begin{array}{l}38.5 \\
(5)\end{array}$ & $\begin{array}{l}15.4 \\
(2)\end{array}$ & 0.3 & 0.65 & 0.35 \\
\hline Total & & 206 & 55 (26.7) & $\begin{array}{l}74 \\
(35.9)\end{array}$ & $\begin{array}{l}77 \\
(37.4)\end{array}$ & $15.4^{*}$ & 0.45 & 0.55 \\
\hline \multicolumn{9}{|c|}{$\begin{array}{l}\chi^{2} \text { tab value: } 3.814\left(\mathrm{df}=1,5 \% \text { LOS); }{ }^{*} \mathrm{P}<0.01 ; \text { rr: Homozygous resistant; rS: Heterozygous; } \mathrm{SS} \text { : }\right. \\
\text { Homozygous susceptible }\end{array}$} \\
\hline \multicolumn{9}{|c|}{ \# Survival in different population corresponding $\mathrm{LC}_{50}$ of the reference population } \\
\hline
\end{tabular}


However, the overall frequency of resistance (' $r$ ') allele was found higher (55.0\%) as compared to susceptible allele (' $S$ '). The correlation co-efficient $(r=0.73)$ between the per cent of survival at $L_{50}$ cypermethrin and resistant allele frequency was significant $(P<0.01)$ in the studied tick populations. There was a positive correlation between the percentage survival at the $\mathrm{LC}_{50}$ concentration and the resistant allele frequency in the populations (Table 4).

\subsection{Sequencing analysis of PCR products}

On sequencing, a random $10 \%$ of samples from each phenotypically cypermethrin-resistant population, the point mutation of thymine to cytosine conferring cypermethrin resistance was present in all thirteen populations tested (100\%; 18/18). Sequencing of 15 single KNL phenotypically susceptible population larvae, too proved the susceptible genotype $(100 \% ; 15 / 15)$. PCR products of sodium channel gene with respect to different genotypes (SS, rr and rS) were sequenced to detect variation if any at the nucleotide level. Transition of $\mathrm{T} \rightarrow \mathrm{C}$ at 2,134 nucleotide position in sodium channel domain III S6 mRNA corresponding to the sequence KU886032. 1 available in NCBI is observed in both the DNA strands in resistant (rr) tick populations, whereas mutation was observed only in single strand in heterozygous (rS) tick populations (Fig. 3).

\section{Discussion}

It is well established fact that ticks are capable to develop resistance to different class of the acaricides used against them so far (Whitehead 1965; Wharton 1976; Nolan and Schnitzerling 1986; Dantas-Torres 2008). In India, acaricidal resistance in cattle ticks using bioassays and genotyping is well documented compared to that of dog ticks. In the present study, thirteen populations (92.9\%) were categorized as resistant to cypermethrin but, the phenotypic level of resistance between the populations varied due to the difference in pet owners' management practices that produce dissimilar acaricide exposure. Only three populations, ATP2, MTM1 and MTM2 showed a high level of resistance ( $\mathrm{LC}_{50}$ : $>9$-fold) and were collected from dogs at veterinary clinics with confirmed history of frequent cypermethrin use. Of two populations collected from Machilipatnam, MTM1 ticks were collected from dog's residence and conferred an LC L0 $_{9} 9.05$ times higher than that of susceptible reference. Nevertheless, MTM2 ticks were collected from dog at veterinary clinic, which had been treated with commercial pet shampoo (cypermethrin 1\% shampoo) weekly for three weeks before sampling. The $\mathrm{LC}_{50}$ value for the larvae of this population $(240.16 \mathrm{ppm})$ was higher significantly than the $\mathrm{LC}_{50}$ value of MTM1 population (187.59 ppm), indicating the effect of repeated treatment on the selection of drug resistant populations. In the present study ELR and BZA1 populations had the lowest cypermethrin resistance level and reported the occasional use of drug. The population regarded susceptible to cypermethrin (KNL) was collected from stray dog and for obvious reasons it is not possible to prove prior exposure to any acaricide. Generally, the evolution of acaricide resistance in a tick population is reliant on the prevalence of resistant individuals and the potency of drug selection pressure in a population (Kunz and Kemp 1994). In addition, inappropriate acaricide application without proper veterinary guidance, improper post treatment animal handling (ex: washing animals with shampoo), re-infestation, using acaricides that remain in the environment at sub-lethal concentrations for a prolonged period or combinations of that (Hawkins et al. 2019) contribute development of resistance to acaricides. It is certainly that $R$. sanguineus 
tick populations were directly and accidentally exposed to synthetic pyrethroids since the 1990's, resulting in selection pressure for resistance.

Acaricides containing synthetic pyrethroids i.e., cypermethrin, permethrin, deltamethrin and flumethrin have been used extensively to control ticks and lice on cattle and dogs throughout India, since long back (information obtained from field veterinarians) that might have contributed to the selection of resistance to pyrethroids in Indian isolates of cattle tick, $R$. microplus populations (Kumar et al. 2020). Alike dog tick, $R$. sanguineus s.I. populations were put forth to similar selection pressure, which resulted in resistance to cypermethrin. In India there is a paucity of information on effectiveness of pyrethroids on $R$. sanguineus ticks. In vitro evaluation of efficacy of deltamethrin and cypermethrin against $R$. sanguineus collected from clinics, Gujarat revealed that ticks were susceptible for cypermethrin and resistant to deltamethrin at the recommended dose (Shyma et al. 2019). The current results were in agreement with those reported earlier. Bioassays carried out on efficacy of pyrethroids against $R$. sanguineus in Panama (Miller et al. 2001), Spain (Estrada-Pena 2005), Texas and Florida (Eiden et al. 2015) and Mexico (Rodriguez-Vivas et al. 2017a) indicated that the pyrethroids are not option for the control of these ticks and the level of resistance may vary among different tick populations where certain $R$. sanguineus populations seem to be highly resistant to pyrethroid acaricides.

A mutation (T2134C) in the domain III segment VI of the sodium channel gene was present in all $R$. sanguineus s.l. populations tested and the populations that carried the mutations showed resistance to cypermethrin in bioassays. Agreeing the present results, earlier study revealed that the domain III segment $\mathrm{VI}$ mutation at location 2,134 conferred resistance in $R$. sanguineus to permethrin (Tucker et al. 2017). Probably the common use of cypermethrin in the study area, where ticks were exposed through earlier on host and environment treatments resulting in selection favoured the mutation in all populations. Though the resistance SNP was present at higher rate in the sodium channel of the Machilipatnam (MTM2) population, RRs of this population is lower than Anantapur (ATP2) population. In addition to sodium channel mutation, the increased metabolic activity leading to acaricide detoxification could have contributed to higher RRs in ATP2 population. Synergist studies indicated increased esterases activity is an important mechanism in $R$. sanguineus tick's resistance to pyrethroid acaricides (Miller 2001; Eiden et al. 2017). Based on bioassay and molecular assay results, it is clear that the SNP was not the primary resistance mechanism in any of the populations sampled. While exploring esterase-mediated and target site insensitivity mechanisms in two permethrin-resistant strains of $R$. microplus, Guerrero et al. (2002) noticed that the two populations exhibited survival at low doses of permethrin through different mechanisms. One population utilized metabolic resistance as the primary survival mechanism, whereas the other population utilized the target site insensitivity mechanism showing that both mechanisms were there in each population.

The simultaneous occurrence of increased metabolic detoxification and target site insensitivity in arthropod parasites is common as was observed previously in Musca domestica (Scott and Georghiou 1986), cattle tick (Jamroz et al. 2000), and mosquitoes (Ochomo et al. 2013) and the relative contribution of metabolic detoxification and target site insensitivity were strain dependent. Likewise, $R$. sanguineus exhibited similar diversification of resistance mechanisms. Despite the RR of BZA2 population is very low (1.72), the homozygous SNP levels were high suggesting the existence of multiple SNPs in sodium channel gene which 
has been disclosed in Haematobia irrtans (Guerrero et al. 1997), Musca domestica (Farnham et al. 1987) and cattle tick, $R$. microplus (Kumar et al. 2013). Dong et al. (2014) reported that over 50 sodium channel mutations are correlated with resistance to pyrethroids in different arthropod vectors. Recently, Tucker et al. (2019) also opined that multiple sodium channel mutations might be responsible for higher resistance to permethrin in certain $R$. sanguineus populations in south Brazil. The molecular assay proved to be a reliable method for detection of genotypic cypermethrin resistance associated target site insensitivity in tick populations. Further studies should include synergist studies to identify level of metabolic detoxification of cypermethrin in this resistant populations and the occurrence of other resistance conferring sodium channel SNPS.

In spite of the beneficial effect of macrocyclic lactones (MLs) as an acaricide, the extensive use over the last few years has brought drug selective pressure and led to the development of resistance in cattle tick, $R$. microplus in India (Singh et al. 2015; Nandi et al. 2018). Yet, MLs are working competently nevertheless it is essential to monitor the situation in order to extend the efficacy of this effective compound. Ivermectin, the most frequently used MLs and is administered in dogs at different concentration, orally or subcutaneous as single or repeated treatments for control of ectoparasites and nematodes. This extensive use particularly at off-label doses in dogs has led to the development of resistance to ivermectin (Campbell 2016). Use of ivermectin as endoparasiticide in cattle herds in Mexico generated resistance in gastrointestinal nematodes and the tick R. microp/us (Alegria-Lopez et al. 2015). Similarly, use of the MLs to eliminate canine endoparasites could also set selection pressure for ivermectin resistance in $R$. sanguineus s.l. infesting dogs.

Of the total $R$. sanguineus populations, six (42.6\%) were categorized as resistant with RR ranging from 1.5 to 4.79 and were with confirmed exposure to ivermectin for four years. The increased resistance in these populations may be due to inconsistent treatments (overuse of one class of drugs, or using ineffective concentrations) or the evolutionary selection pressure that a chemical exerts on a tick population. In accordance to the present results Becker et al. (2019) observed lower resistant ratios in R. sanguineus s.s populations in Brazil (RR up to 2.97). However, Rodriguez-Vivas et al. (2017b) found brown dog tick populations with higher resistance ratios in Yucatan, Mexico (RR up to 30.5). The variation among the resistance levels between populations might be correlated to variation in the frequency of exposure to ivermectin. The greatest ivermectin resistant tick population (BZA2, RR $=4.79)$ was found in the Municipal Corporation of Vijayawada. This population has been treated with ivermectin, cypermethrin, and fipronil for three years. Surprisingly, these ticks expressed considerable susceptibility to cypermethrin alongside intermittent on animal cypermethrin applications. This could be reduced usage of cypermethrin against tick infestation as reported in Veterinary Clinics of Vijayawada following introduction of fipronil in the market.

Most of the pet owners in the study area (Tanuku, Eluru, Machilipatnam, Kadapa) claimed that ivermectin was ineffective for controlling their tick problem, while the bioassay results revealed susceptibility to ivermectin. Under these circumstances it is difficult to determine the reason for lack of success. Generally, inconsistent or improper product use may be occurring that lead to reduced chemical exposure levels for ticks. Further, changes in tick distributions and densities along with owner perception may have a direct impact upon success or failure of an acaricide. Usually, pet owners regard lack of efficacy of an acaricide even dog experiences just a few ticks following treatment of heavily tick infested dog with effective acaricide. 
Thus, it is not uncommon that label recommended application of a product does not appear to control the problem (Dryden 2009). Detoxification mechanisms mediated by ATP binding cassette (ABC) transporters were observed to be the most important in ivermectin resistance in $R$. microplus (Pohl et al. 2011). Alike, ABC transporters may also play a role in ivermectin detoxification in $R$. sanguineus s.l. (Cafarchia et al. 2015). This study reports for the first time occurrence of ivermectin resistant populations of $R$. sanguineus s.l. in India. Further studies on role of ABC transporters in resistant mechanism of these tick populations are warranted.

\section{Conclusion}

In conclusion, dogs in the state of AP, south India are infested with $R$. sanguineus s.I. and are moderately resistant to ivermectin and highly resistant to cypermethrin which is concerned. Further use of these drugs against ticks in dogs may cause continued selection for resistant tick populations in addition to high rate of therapeutic failures. To prevent further resistance selection, education of veterinarians regarding the use of different classes of acaricides rotationally, maintenance of refugia that allow repository of drug-susceptible genes and targeted selective treatment is vital.

\section{Declarations}

\section{Acknowledgement}

The authors are thankful to Sri Venkateswara Veterinary University, Tirupati, India, for providing the facilities to do the research work.

\section{Funding}

This study received no funding

\section{Author contribution}

Conceptualization: Sreedevi Chennuru, Prathyusha Sunkara, Formal analysis: Sudhakar Krovvidi, Investigation: Prathyusha Sunkara, Krovvidi Sudhakar Methodology: Sreedevi Chennuru, Sudhkar Krovvidi, Jyothisree Chitichoti, Writing - original draft: Sreedevi Chennuru, Prathyusha Sunkara, Writing - review and editing: Sreedevi Chennuru, Sudhkar Krovvidi, Jyothisree Chitichoti

\section{Ethical statement}

No experimentation was conducted on animals. Ticks were collected from dogs attending to the veterinary dispensaries and hence doesn't necessitate for ethical approval. Study animals were subjected to minimum stress while collecting ticks.

\section{Consent to participate}

All authors contributed to the study conception and design. All authors read and approved the final manuscript. 


\section{Consent for publication}

All authors gave their consent for research publication.

\section{Conflicts of interest}

The authors declare that there is no conflict of interest.

\section{Code availability}

Not applicable.

\section{References}

1. Alegria-Lopez MA, Rodriguez-Vivas RI, Torres-Acosta JFJ, Ojeda-Chi MM, Rosado-Aguilar JA (2015) Use of ivermectin as endoparasiticide in tropical cattle herds generates resistance in gastrointestinal nematodes and the tick Rhipicephalus microplus (Acari: Ixodidae). J Med Entomol 52(2):214-221

2. Becker S, Webster A, Doyle RL, Martins JR, Reck J, Klafke GM (2019) Resistance to deltamethrin, fipronil and ivermectin in the brown dog tick, Rhipicephalus sanguineus sensu stricto, Latreille (Acari: Ixodidae) Ticks Tick Borne Dis 10(5): 1046-1050

3. Brengues C, Hawkes NJ, Chandre F, McCarroll L, Duchon S, Guillet P, Hemingway J (2003) Pyrethroid and DDT cross-resistance in Aedes aegypti is correlated with novel mutations in the voltage-gated sodium channel gene. Med Vet Entomol 17(1):87-94

4. Cafarchia C, Porretta D, Mastrantonio V, Epis S, Sassera D, latta R, Otranto D (2015) Potential role of ATPbinding cassette transporters against acaricides in the brown dog tick Rhipicephalus sanguineus sensu lato. Med Vet Entomol 29(1):88-93

5. Campbell WC (2016) Lessons from the history of ivermectin and other antiparasitic agents. Annu Rev Anim Biosci 4:1-14

6. Cen-Aguilar JF, Rodriguez-Vivas RI, Dominguez-Alpizar JL, Wagner GG (1998) Studies on the effect of infection by Babesia species on oviposition of Boophilus microplus engorged females naturally infected in the Mexican. tropics Vet Parasitol 78(4):253-257

7. Dantas-Torres F (2008) The brown dog tick, Rhipicephalus sanguineus (Latreille, 1806) (Acari: Ixodidae): from taxonomy to control. Vet Parasitol 152(3-4):173-185

8. Dong K, Du Y, Rinkevich F, Nomura Y, Xu P, Wang L, Zhorov BS (2014) Molecular biology of insect sodium channels and pyrethroid resistance Insect. Biochem Mol Biol 50:1-17

9. Dryden MW (2009) Flea and tick control in the 21 st century: challenges and opportunities. Vet Dermatol 20(5-6):435-440

10. Eiden AL, Kaufman PE, Oi FM, Allan SA, Miller RJ (2015) Detection of permethrin resistance and fipronil tolerance in Rhipicephalus sanguineus (Acari: Ixodidae) in the United States. J Med Entomol 52(3):429436

11. Eiden AL, Kaufman PE, Oi FM, Dark MJ, Bloomquist JR, Miller RJ (2017) Determination of metabolic resistance mechanisms in pyrethroid-resistant and fipronil-tolerant brown dog ticks. Med Vet Entomol 
31(3):243-251

12. Estrada-Pena A (2005) Etude de la resistance de la tique brune du chien, Rhipicephalus sanguineus aux acaricides. Rev Med Vet 156(2):67-69

13. Falconer DS, Mackay TFC (2009) Introduction to quantitative genetics (4th edition). Pearson Education Ltd, United Kingdom

14. FAO: Food and Agriculture Organization of the United Nations (1971) Recommended methods for the detection and measurement of resistance of agricultural pests to pesticides-tentative method for larvae of cattle ticks, Boophilus microplus species FAO method No 7 FAO. Plant Prot Bull 19:15-18

15. FAO: Food and Agriculture Organization (2004) Resistance management and integrated parasite control in ruminants-guidelines, module 1-ticks: acaricide resistance: diagnosis, management and prevention, pp 25-77

16. Farnham AW, Murray AWA, Sawicki RM, Denholm I, White JC (1987) Characterization of the structureactivity relationship of kdr and two variants of super-kdr to pyrethroids in the housefly (Musca domestica L). Pest Manag Sci 19:209-220

17. Guerrero FD, Davey RB, Miller RJ (2001) Use of an allele-specific polymerase chain reaction assay to genotype pyrethroid resistant strains of Boophilus microplus (Acari: Ixodidae. J Med Entomol 38(1):4450

18. Guerrero FD, Jamroz RC, Kammlah D, Kunz SE (1997) Toxicological and molecular characterization of pyrethroid-resistant horn flies, Haematobia irritans: identification of kdr and super-kdr point mutations Insect. Biochem Mol Biol 27(8-9):745-755

19. Guerrero FD, Li AY, Hernandez R (2002) Molecular diagnosis of pyrethroid resistance in Mexican strains of Boophilus microplus (Acari: Ixodidae. J Med Entomol 39(5):770-776

20. Hawkins NJ, Bass C, Dixon A, Neve P (2019) The evolutionary origins of pesticide resistance. Biol Rev 94(1):135-155

21. Jamroz RC, Guerrero FD, Pruett JH, Oehler DD, Miller RJ (2000) Molecular and biochemical survey of acaricide resistance mechanisms in larvae from Mexican strains of the southern cattle tick. Boophilus microplus J Insect Physiol 46(5):685-695

22. Klafke GM, Miller RJ, Tidwell J, Barreto R, Guerrero FD, Kaufman PE, Perez de Leon AA (2017) Mutation in the sodium channel gene corresponds with phenotypic resistance of Rhipicephalus sanguineus sensu lato (Acari: Ixodidae) to pyrethroids. J Med Entomol 54(6):1639-1642

23. Kumar R, Nagar G, Sharma AK, Kumar S, Ray DD, Chaudhuri P, Ghosh S (2013) Survey of pyrethroids resistance in Indian isolates of Rhipicephalus (Boophilus) microplus: identification of C190A mutation in the domain II of the para-sodium channel gene. Acta Trop 125(2):237-245

24. Kumar R, Sharma AK, Ghosh S (2020) Menace of acaricide resistance in cattle tick. Rhipicephalus microplus in India: Status possible mitigation strategies Vet Parasitol 278:108993

25. Kunz SE, Kemp DH (1994) Insecticides and acaricides: resistance and environmental impact. Rev sci tech Off int Epiz 13(4):1249-1286

26. Latreille PA 1806 Genera crustaceorum et insectorum secundum ordinem naturalem in familia disposita, iconibus exemplisque plurimis explicate Paris et Argentorati 1: 302 
27. Mathivathani C, Basith SA, Latha BR, Raj GD (2011) In vitro evaluation of synthetic pyrethroid resistance in Rhipicephalus sanguineus ticks of Chennai. J Vet Parasitol 25(1):56-58

28. Miller RJ, George JE, Guerrero F, Carpenter L, Welch JB (2001) Characterization of acaricide resistance in Rhipicephalus sanguineus (Latreille) (Acari: Ixodidae) collected from the Corozal army Veterinary quarantine center. Panama J Med Entomol 38(2):298-302

29. Nandi A, Sagar SV, Chigure G, Fular A, Sharma AK, Nagar G, Ghosh S (2018) Determination and validation of discriminating concentration of ivermectin against Rhipicephalus microplus. Vet Parasitol 250:30-34

30. Needham GR, Teel PD (1991) Off-host physiological ecology of ixodid ticks. Annu Rev Entomol 36(1):659-681

31. Nolan J, Schnitzerling HJ (1986) Drug resistance in arthropod parasites. In: Chemotherapy of parasitic diseases. WC, Campbell, New York, pp 603-620

32. Ochomo E, Bayoh MN, Brogdon WG, Gimnig JE, Ouma C, Vulule JM, Walker ED (2013) Pyrethroid resistance in Anopheles gambiae ss and Anopheles arabiensis in western Kenya: phenotypic, metabolic and target site characterizations of three populations. Med Vet Entomol 27(2):156-164

33. Pohl PC, Klafke GM, Carvalho DD, Martins JR, Daffre S, da Silva Vaz I Jr, Masuda A (2011) ABC transporter efflux pumps: a defense mechanism against ivermectin in Rhipicephalus (Boophilus) microplus. Int J Parasitol 41(13-14):1323-1333

34. Rodriguez I, Fraga J, Noda AA, Mayet M, Duarte Y, Echevarria E, Fernandez C (2014) An alternative and rapid method for the extraction of nucleic acids from ixodid ticks by potassium acetate procedure. Braz Arch Biol Technol 57(4):542-547

35. Rodriguez-Vivas RI, Ojeda-Chi MM, Trinidad-Martinez I, Bolio-Gonzalez ME (2017a) First report of amitraz and cypermethrin resistance in Rhipicephalus sanguineus sensu lato infesting dogs in Mexico Med Vet Entomol 31(1): 72-77

36. Rodriguez-Vivas RI, Ojeda-Chi MM, Trinidad-Martine I, De Leon AP (2017b) First documentation of ivermectin resistance in Rhipicephalus sanguineus sensu lato (Acari: Ixodidae. Vet Parasitol 233: 9-13

37. Scott JG, Georghiou GP (1986) Mechanisms responsible for high levels of permethrin resistance in the house. fly Pestic sci 17(3):195-206

38. Shyma KP, Singh V, Gupta JP (2019) In vitro evaluation of effectiveness of synthetic pyrethroids against brown dog tick. Indian J Anim Res 53(10):1400-1402

39. Singh NK, Singh H, Prerna M, Rath SS (2015) First report of ivermectin resistance in field populations of Rhipicephalus (Boophilus) microplus (Acari: Ixodidae) in Punjab districts of India. Vet Parasitol 214(12):192-194

40. Sowjanya M (2019) Epidemiological surveillance of ectoparasitic infections in dogs in krishna-godavari zone of Andhra Pradesh. Thesis submitted to Sri Venkateswara Veterinary University Tirupati, Andhra Pradesh, India

41. Tucker NS, Kaufman PE, Weeks EN, Rowland J, Tidwell J, Miller RJ (2017) Characterization of a sodium channel mutation in permethrin-resistant Rhipicephalus sanguineus (Acari: Ixodidae). J Med Entomol 54(6):1633-1638 
42. Tucker NS, Kaufman PE, Weeks EN (2019) Identification of permethrin and etofenprox cross-tolerance in Rhipicephalus sanguineus sensu lato (Acari: Ixodidae). Pest Manag Sci 75(10): 2794-2801

43. Wharton RH (1976) Tick-borne livestock diseases and their vectors 5 Acaricide resistance and alternative methods of tick control. World Anim Rev 20:8-15

44. Whitehead GB (1965) Resistance in Acarina: ticks. Adv Acarol 2:53-70

\section{Figures}

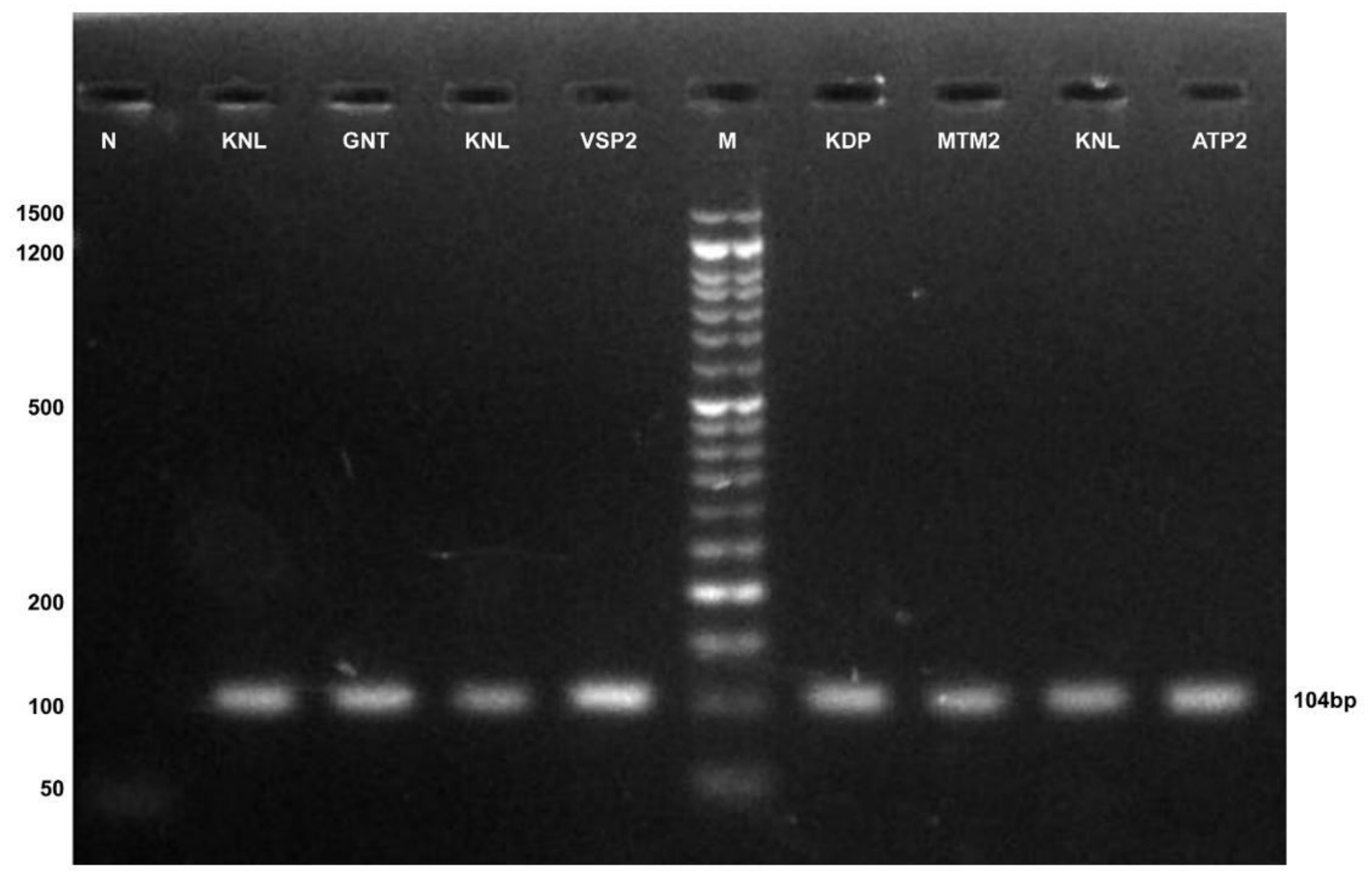

\section{Figure 1}

Amplicons of sodium channel gene employed for sequencing. N: Negative control; M: 50 bp ladder 


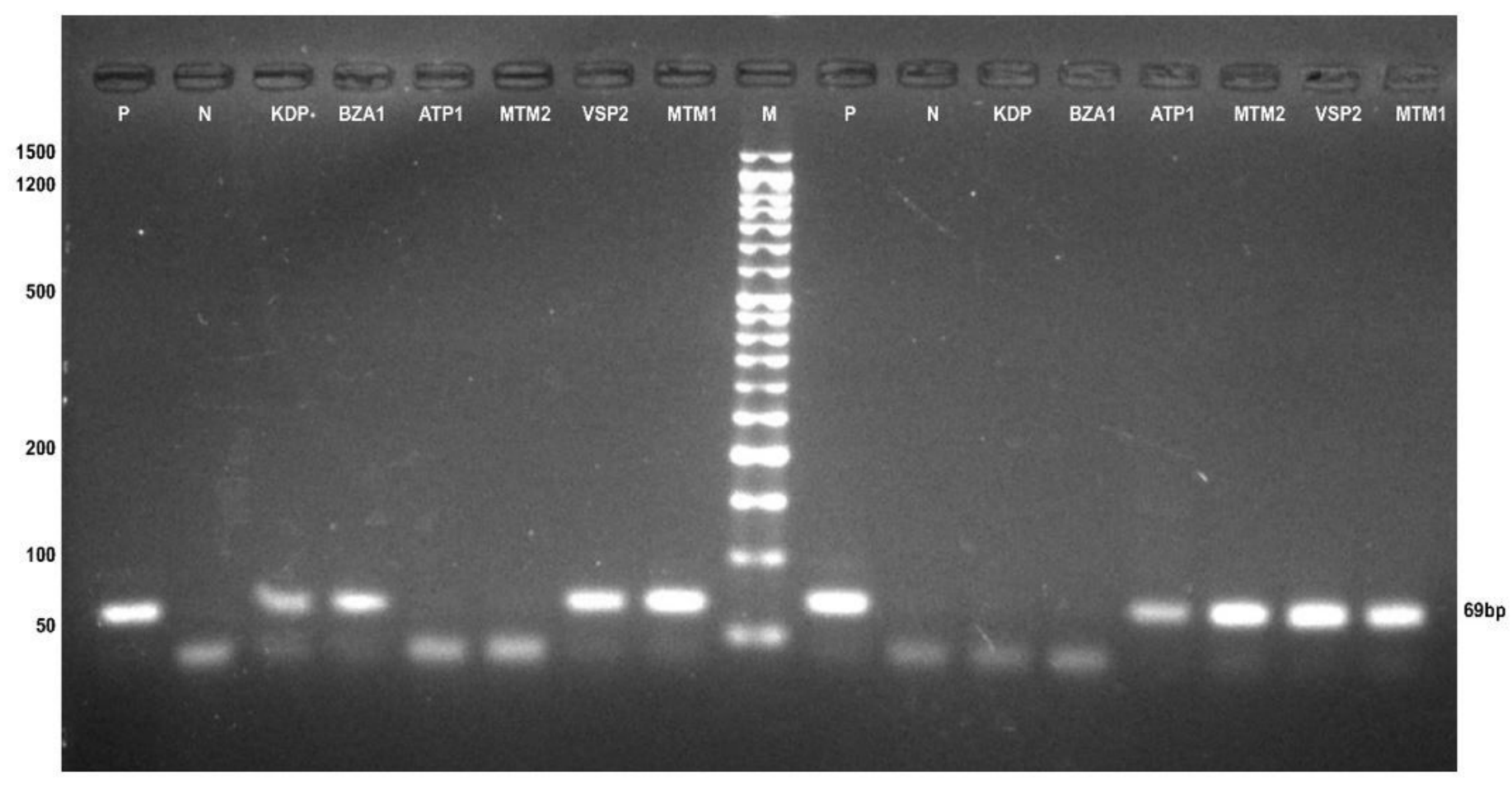

\section{Figure 2}

Screening of different R. sanguineus larval populations to identify resistant genotypes. N: Negative control; P: Positive control for susceptible/resistance genotype; M: 50bp ladder; KDP, BZA1: 'SS' genotypes; ATP1, MTM2: 'rr' genotypes; VSP2, MTM1: 'rS' genotypes 


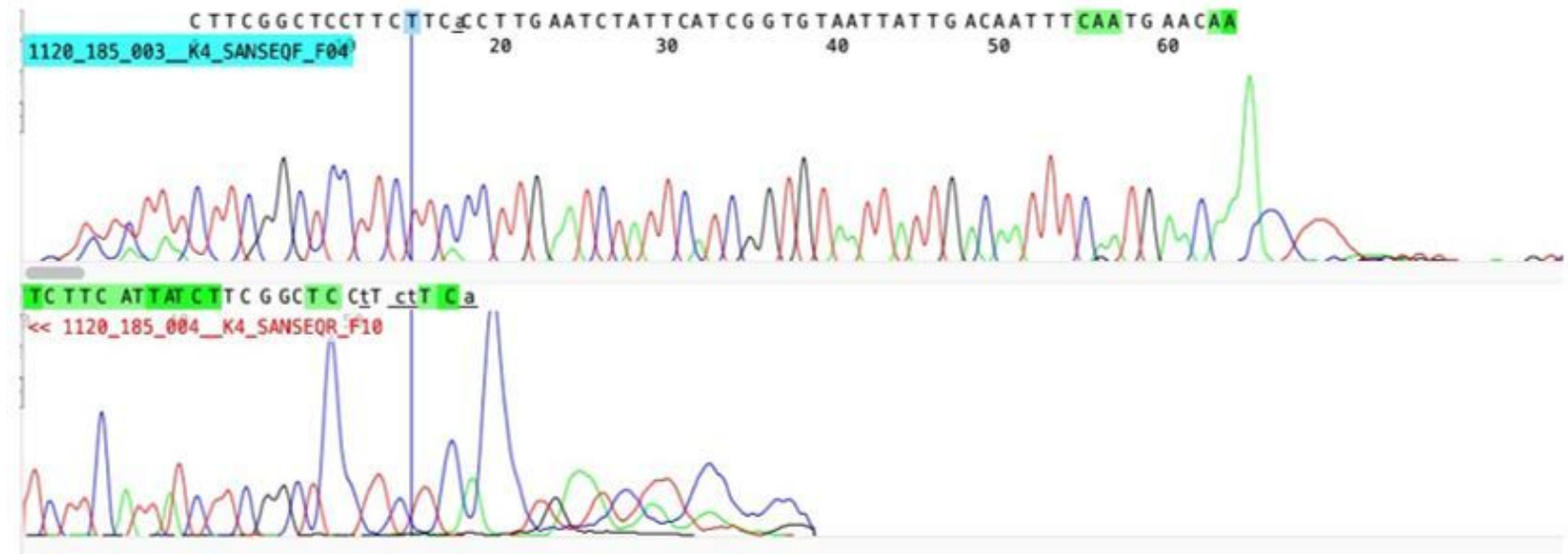

(a) Homzygous for $\mathrm{T}$

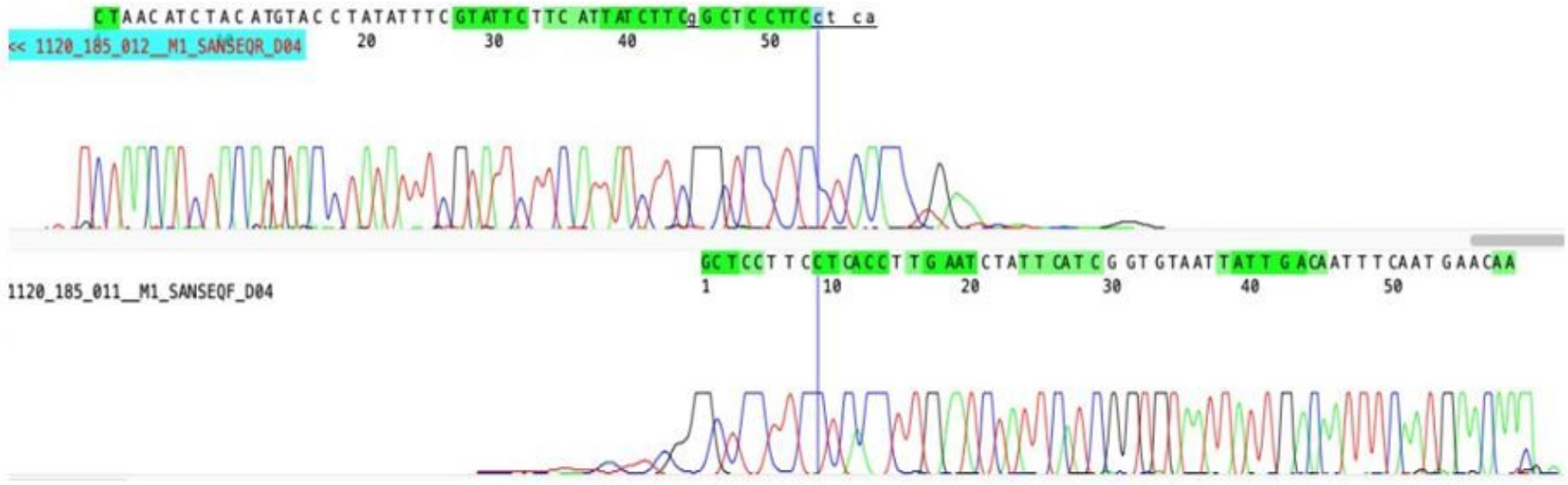

(b) Homzygous for C

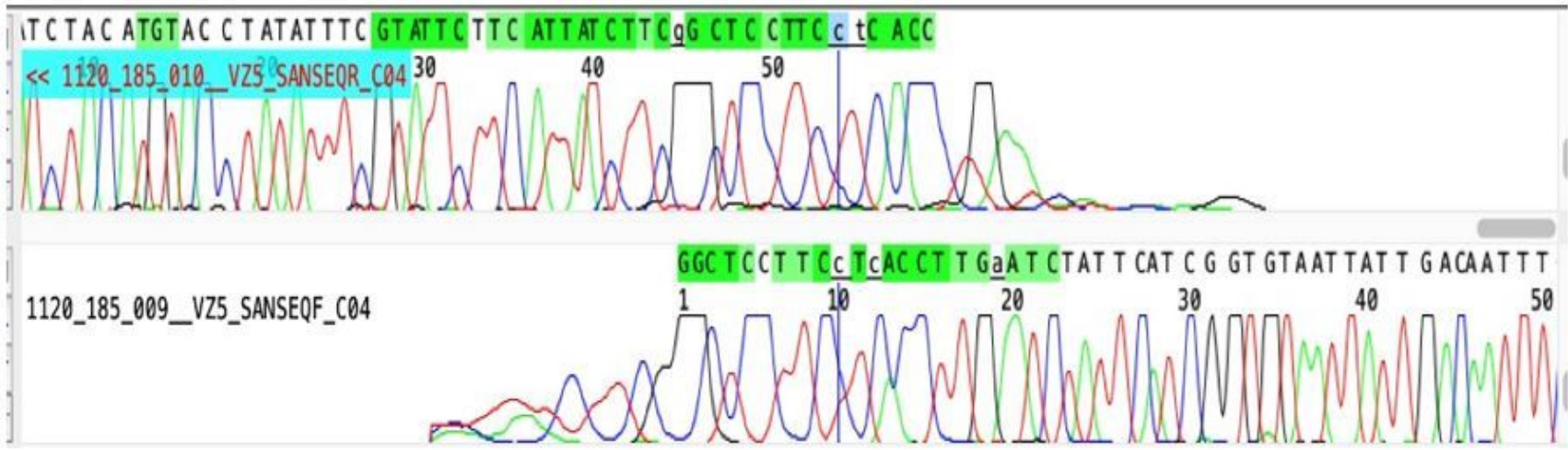

(c) Heterozygous CT

\section{Figure 3}

Chromatogram showing the $\mathrm{T} \rightarrow \mathrm{C}$ transition in sodium channel domain III S6 mRNA of resistant population of R. sanguineus sensu lato

\section{Supplementary Files}

This is a list of supplementary files associated with this preprint. Click to download. 
- Supplementarydatal.doc

- Suppementarydatall.doc 